\title{
CLOSURES OF DEMOCRATIC SPACES? PROFESSIONAL ASSOCIATIONS AND CORRUPTION IN 2010
}

\begin{abstract}
Ridding a country of any kind of corruption, including corruption in procurement, is a long journey and 'A journey of a thousand miles begins with a single step' [Confucius]. Tanzania has not yet reached the end of this long journey, and this applies to many countries, but we have made not a single, but many steps into the journey and we wish the stakeholders to recognise and appreciate these efforts. ${ }^{1}$
\end{abstract}

\section{Introduction}

The intention of this chapter is to explore the patterning of discourses of corruption by professional associations over time. In one way, the conclusions of the case-study in 2003 are rather weak, deprived of grounds for a strong or predictive statement. Perhaps the ambiguous terrain mapped out in 2003 is also a function of the relative novelty of discourses and representations of corruption in the construction sector at the time, with nodal points still being sought and forged. In another way, the case-study is very revealing, crystallising the political struggles that seek to frame and fixate a certain order of things, universalise particular differences, and connect them up to other particular representations. The case-study also illustrated some of the modifications and transformations that professional identities have undergone in the course of hegemonising representations-both in terms of constructing professional identities as well as in terms of collapsing professional identities.

Now, seven years later, a second snap shot is taken, mirroring as far as possible the analysis of 2003 , with the objective of capturing the practices and orders of discourses on corruption. In other words, the objective is not to 'validate' hypotheses carved out of the findings of the case-study of 2003. The objective is to provide a denser representation of the dynamics

1 This is a statement by the CEO of the Public Procurement Regulatory Authority in the PPRA's quarterly journal (see PPRA 2009: 4). 
of social change, i.e. to understand practices, struggles and the trajectories of discursive representations of corruption over time.

A word on the extent to which the case-studies discussed in the previous and this chapter are mirrored. The qualitative methodological approach of both case-studies does not pave the way for an exact comparison that, in any case, might prevent the recognition of discursive dynamics. This second case-study is undertaken with a lens focused on the politics of corruption, rather than on manifestations of corruption, which was the original focus of the case-study of 2003. The structure of the study remains grosso modo the same, sketching out firstly the macro-context of politics and corruption reforms, secondly, the meso-level of (changes in) the institutional framework and key actors of the construction industry, and thirdly, the representations of corruption by professional associations of the construction industry. In a last step, the observed dynamics will be synthesised, analysing the hegemonic power of emancipatory discourses of corruption, and seeking to understand the specific processes of ordering differentials over time more clearly.

\section{Jakaya Kikwete-'A dedicated spirit of government'?2}

At the end of the era Mkapa, Tanzania had a wide public awareness of corruption and a diverse set of governance and anti-corruption institutions. Under President Kikwete the fight against corruption did not receive quite the same prominence as it did under President Mkapa. At the beginning of his presidency in 2005 , President Kikwete ${ }^{3}$ did send a strong signal by (re-)appointing two respected persons as heads of key anti-corruption institutions, namely of the Prevention of Corruption Bureau (PCB) and the Auditor General. Also, the Prevention of Corruption Bureau was endowed with greater autonomy in 2007 , granting it further investigative powers and upgrading to the Prevention and Combating of Corruption Bureau (PCCB). Further reforms include the amended anti-corruption bill, which was also passed in 2007, and the Enhanced National Anti-corruption Strategy (2006-2010) launched in the same year (see sections below).

2 This alludes to a response by one of the interviewed contractors (see below).

${ }^{3}$ President Jakaya Kikwete was elected in 2005, and at the time of writing his first term in office is coming to an end. Legislative as well as presidential elections are scheduled for 31 October 2010. For more information see the website of the International Foundation on Electoral Systems (IFES) under http://www.electionguide.org/country.php?ID=211 (last accessed 8 May 2010). 
At the same time, however, Tanzania had been shaken by a series of major corruption scandals that seemed to indicate that corruption was not receding. On the contrary, revelations of a system of grand corruption involving senior public officials, domestic private sector representatives and foreign companies in a context of relative impunity seemed to chase each other. ${ }^{4}$ Although these cases date back to the era Mkapa, the jury is still out with regard to President Kikwete's dedication and seriousness about acting against corruption. Under his watch some massive corruption scandals have been exposed, involving key government institutions such as the Bank of Tanzania ${ }^{5}$ and the sacking of the Central Bank Governor, or the resignation of his Prime Minister and two further Ministers due to their complicity in a huge corruption deal that has become known as the Richmond Scandal. ${ }^{6}$ Unlike under Benjamin Mkapa, these cases have been dealt with through due process and debated in the public realm. But as an observer remarked in 2007 , discussing Tanzania's grand corruption schemes: "Hopes that the new government would be able to curb corruption are evaporating as disputed projects continue to gain approval

${ }^{4}$ For instance, the alleged corruption scandal involving USD 40 million in a government deal with British Aerospace for a radar system; the USD 47 million for the purchase of the presidential jet; the major corruption allegations with regard to the building of the USD 350 million Bank of Tanzania Twin Towers, which, according to experts, were double the costs of similar constructions in Tokyo or London; or the corruption scams under various privatisation schemes, most prominently the IPTL power supply contract involving the national power company Tanesco and several foreign companies (see, for instance, the article on "Governance and Corruption in Tanzania: 1995-2005" detailing corruption cases under http://www.bongotz.com/news.html, last accessed 20 April 2010; or the article on Tanzania Corruption Tracker "How corruption 'eats' Tanzanian taxpayers' hard earned revenue", under http://www.corruptiontracker.or.tz/, last accessed 20 April 2010; or Hussman/Mmuya 2007).

5 The grand corruption cases of the era Mkapa include the Bank of Tanzania's External Payment Arrears Account (EPA) scandal; at the time of writing (2009), at least 13 individuals are in court over the 2005 scandal where the government paid USD 105.5 million to companies using flawed or nonexistent records from the central bank's External Payment Arrears Account. Also, the former president is himself implicated in a privatisation deal of a coal mine allegedly made corruptly and fraudulently (see, for instance, Tanzania Affairs, "Corruption-Crusade Continues", 28 September 2008, under http://www.tzaffairs. org/2008/og/corruption-crusade-continues/; last accessed 13 October 2009).

6 They resigned after clear implications of their involvement in the Richmond scandal, a contract with a mirage company for emergency power supply that swallowed over USD 170 million from public funds. See, for instance, "Tanzania PM to resign over graft", BBC World News, 7 February 2008 under http://news.bbc.co.uk/2/hi/africa/7232141.stm (last accessed 14 September 2009); or Tanzania Affairs, "Corruption-Crusade Continues", 28 September 2008, under http://www.tzaffairs.org/2008/og/corruption-crusade-continues/ (last accessed 13 October 2009). 
from the executive." ${ }^{7}$ So in spite of the exemplary investigation into some cases, the extent of corruption in the public sector does not seem to have receded significantly. In fact, both the World Bank ${ }^{8}$ and Norway ${ }^{9}$ have recently sent some powerful signals, by threatening to reduce funds to Tanzania, justified on different accounts by corruption and lack of transparency and accountability.

Perhaps against this backdrop, 'zero tolerance of corruption' as a priority policy has not been wiped off the agenda. With the general elections coming up in 2010, at the time of writing President Kikwete has reactivated the national anti-corruption campaign. He began his campaign for a second term with a spectacular criticism of his own government officials. According to a leading national newspaper, speaking at the inauguration of the PCCB House in Dar es Salaam on September 10, 2009, the President

said that 30 per cent of the Government Budget was embezzled through big investment and contractual projects and in public procurement by civil servants. Of the Shy trillion 2009/2010 Budget, the theft of 30 per cent by government officials would amount to a whopping $\mathrm{Sh}_{3}$ trillion. This is almost equal to the 34 per cent that donors are expected to provide for development project. ${ }^{10}$

This may well be the beginning of a newly, invigorated anti-corruption stance of the government. On the other hand, there are indications that the ruling party, CCM, is only willing to have corruption cases addressed in which leading party members are not implicated. Nearly simultaneously with the President's outspoken critique of corrupt public officials, the National Executive Committee (NEC), the governing body of the CCM, established a three-person-team, lead by former President Ali Hassan Mwinyi, to restore party unity and enforce party discipline at the August NEC-CCM convention—a unveiled paraphrase for curtailing

7 See Sebastian Sanga (Tanzania: Reporter's Notebook, Global Integrity Report, Assessment 2007) under http://report.globalintegrity.org/Tanzania/2007/notebook (last accessed 5 March 2010).

8 The latest Country Performance Rating of the World Bank shows poor performance of Tanzania on key lending criteria. According to newspaper articles, Tanzania stands to lose about USD 312 Million Dollars in soft loans in from 2010-2013 (see The Citizen, Friday 11 September, or The Sunday Citizen, Sunday 13 September 2009).

9 Norway has been threatening to withhold funds due to entrenched corruption in natural resource management programmes funded by Norway. For a synopsis see http://commons.globalintegrity.org/2009/04/headlines-in-tanzania-millions-go.html (last accessed 14 September 2009); for the full report see Jansen 2009.

10 See The Sunday Citizen, Sunday 12 September 2009, under http://www.thecitizen. co.tz/newo.php?id=13771 (last accessed 13 September 2009). 
critical voices within the party. The following account of the party convention makes the general atmosphere within the party very clear:

It is understood that during the highly-charged Dodoma meeting, more than 40 NEC members launched direct attacks on Sitta [the Speaker of the National Assembly] and other 'rebel' MPs for speaking out against high-level corruption in government.

They accused the Speaker of 'embarrassing' the government by allowing MPs during the recent parliamentary budget session to openly criticize senior public leaders, both past and present, and there were several calls for Sitta's immediate expulsion from the party and replacement as House Speaker.

An official CCM statement issued after the meeting said merely that all ruling party cadres-particularly MPs_-had been banned forth with from speaking out on widespread corruption and abuse of office allegations against ex-president Mkapa. Nothing else was said."11

In other words, the signs of increasing party monopoly and especially of top-down control of party discipline that was already observed under Mkapa seems to be in the process of being formally consolidated. ${ }^{12}$ The question where that leaves the political exposure of corruption and unethical behaviour of senior officials is open. Obviously, the internal debates within the CCM are being shut down, perhaps because leading members voice their opposing views. In marked contrast to 2003, however, the opposition party, Chadema, has gained considerable traction. It has grown in size and media presence, and its leaders, prominent members of the public, do not seem to be afraid (anymore) of addressing contentious issues and challenging government accountability. Although the proof will be in the 2010 elections, Chadema seems to provide a viable alternative for disaffected CCM MPs and voters.

It seems that in the past seven years two trends can be observed in Tanzania: on the one hand, large-scale corruption cases that occurred in the early to mid-20oos have been exposed; their occurrence can be explained simply through the increase in available funds (FDI and foreign aid), the institutional voids and loopholes during the rapid reform process, and not

11 The CCM-NEC session was recounted in This Day, one of the most outspoken and courageous English newspapers in Tanzania, on Friday, 18. September, in its frontline story "Msekwa gives his version of events" (pp. 1-2) (Mr Msekwa is the CCM vice-chairman). The excerpt is taken from page 2 .

12 The enforced party discipline makes the unspoken rules evident. Also, this increased tendency towards authoritarianism has been noted in several academic contributions. See, for instance, Skinlo 2007 or Hyden/Mmuya 2008. 
least through the consolidation of political and economic power of the CCM, which was the ruling party during Julius Nyerere's socialist era, and has been in power since the first multi-party elections in 1986. On the other hand, the fact that these cases have found their way into the public realm and the justice sector is also significant. The same period has seen a remarkable change in the legal and institutional framework designed to prevent and sanction corruption. The reforms will be discussed below; suffice to note at this point that although their performance and implementation is uneven, the opening of political spaces and the hardening of legal practices, as evidenced in the prosecution of high-level corruption cases, may point towards a process in which time plays a greater role than it is usually accorded. Just how this process is to be assessed is open. Two quotes from two very knowledgeable Tanzanians, both prominent corruption experts in their own right, illustrate the discrepancy. When I asked them (separately) about the meaning of these grand corruption cases, the opinion of one was that it pointed towards an increased criminalisation of the state, to a tightening of the political elite and a handful of (mostly Indian) financial 'advisors' that were still protected in a tightly-knit web of impunity. The other person's opinion was more sanguine: "It was a window which is being shut now".

I shall now outline the institutional reforms aimed at shutting this window, undertaken in the period between 2003 and early 2010. This section provides an overview over national governance reforms, with the section following it zooming in on reforms in the construction sector. Both outline the institutional and policy framework of the realities of the professional associations that will be explored in the last sections of this chapter.

\section{Governance and Anti-Corruption Reforms in the Regulatory Framework}

\subsection{National Strategy for Growth and the Reduction of Poverty 2005-2010 $(\text { MKUKUTA })^{13}$}

The MKUKUTA is the national framework guiding social and economic policies for poverty reduction. 'Governance and accountability' constitutes

13 MKUKUTA stands for 'Mkakati wa Kukuza Uchumi na Kupunguza Umaskini Tanzania', the commonly used Swahili acronym of the National Strategy for Growth and Poverty Reduction. 
one of three clusters of poverty reduction, indeed, according to the MKUKUTA, it "provides the bedrock [...] for broad-based growth and improvement of quality life and social well-being to take place [...]. Human rights, a functioning and fair justice system and the war against corruption are key elements of this cluster" (MKUKUTA 2005: 31). The box below details its strategic objectives:

Box 1. MKUKUTA Cluster III-Goals and Targets for Governance and Accountability

- Structures and systems of governance as well as the rule of law are democratic, participatory, representative, accountable and inclusive.

- Ensure representative, inclusive (poor and vulnerable groups) and accountable governance institutions at all levels.

- Equitable allocation of public resources with corruption effectively addressed.

- Public resources are allocated, accessible and used in an equitable, accountable and transparent manner.

- Institute effective regulations and mechanisms regarding petty and grand corruption.

- Effective public service framework in place to provide foundation for service delivery improvements and poverty reduction.

- Administrative systems of public institutions are managed transparently and in the best interests of the people they serve.

(Source: MKUKUTA 2005: 50)

Tanzania's poverty reduction objectives are supported by international donors through budget support and country assistance programmes. ${ }^{14}$ Recently, a supplemental credit of USD 171 million has been pledged by the World Bank, specifically to help implement the MKUKUTA. According

14 An edition of 'Development and Cooperation' dedicated to Tanzania in 2009 circumscribes the role of foreign aid and poverty reduction in the following way: "From 2005 to 2010, the government of Tanzania is implementing a strategy called MKUKUTA to combat poverty and boost growth. The strategy includes crucial institutional reforms such as political devolution and anti-corruption measures. [R] oughly a third of state activities and expenditures are financed with funding from donors at present". The article goes on to describe the budget-support provided to Tanzania, which is only one of many forms of foreign aid: "In the current financial year (2008/09), 14 donors are contributing a total of $\$ 750$ million to Tanzania's national budget. This amount makes up $12 \%$ of the budget and a full third of all donor spending. The UK and the World Bank are the main budget-support donors, each contributing around 25\%. Germany's share is below two per cent" (Spitzer/ Fleuth-Leferink 2009, available online under http://www.inwent.org/ez/articles/og2482/ index.en.shtml; last accessed 25 March 2010). 
to an online article on the TanzaniaInvest website, in this context the World Bank country director emphasised again the "added urgency to Tanzania's efforts to improve the business environment and strengthen governance, in particular the fight against corruption". ${ }^{15}$ The MKUKUTA is also explicitly referred to as a frame of reference in the new national anti-corruption strategy (NACSAP II) (see below), along with other major reform programmes of the justice system and public administration.

\subsection{The Enhanced National Anti-Corruption Strategy 2006-2011 (NACSAP II)}

In the MKUKUTA, the enforcement of NACSAP is mentioned as one specific priority (MKUKUTA 2005: 51). NACSAP II (2006-2010) is the second phase of NACSAP I. It represents a continued official recognition of the importance anti-corruption efforts and a reaffirmation of the goverment's zero-tolerance of corruption:

Corruption in public life undermines good governance and economic growth, distorts national development, and retards the general welfare of the citizens, particularly the poor and vulnerable in society. Considering these ill effects, the Government of Tanzania will maintain a zero tolerance for all acts of corruption, petty or grand, in the use of state resources, create public awareness, and engage all stakeholders in preventing and combating the vice (PCCB 2008: 1).

At the same time, it seeks to address and overcome some of the weaknesses experienced in the implementation of NACSAP I: "Considering that preventing and combating corruption is necessarily a long and tedious undertaking that requires patience, regular reviews, and innovations, the Government has decided to introduce a more robust and comprehensive NACSAP II" (PCCB 2008: 6). The new strategy emphasises the importance of 'partnership', aiming to strengthen strategic collaborations between governmental authorities, and broaden societal engagement against corruption by reaching out to the private sector and civil society.

15 See "World Bank funds Tanzania's MKUKUTA strategy" of Monday 11 January 2010; under http://www.tanzaniainvest.com/tanzania-economy/news/35-news/374-world-bankfunds-tanzania-mkukuta-national-growth-strategy (last accessed 25 March 2010). 
Box 2. Goals of NACSAP II

1. Combat corruption in a more scientific way and by addressing its root causes;

2. Strengthen anti-corruption mechanisms at all the MDAs;

3. Introduce systems of integrity, accountability and transparency in Local Government Administrations (LGAs);

4. Mainstream and empower the Private sector into anticorruption;

5. Mainstream and empower CSOs and other non-state actors into the anticorruption process;

6. Raise public awareness of anticorruption;

7. Build synergy between NACSAP and Legislative and Judicial Integrity Programs;

8. Enhance the capacity of PCCB, GGCU and Director of Public Prosecution to deal with corruption, manage and implement NACSAP.

(Source: PCCB 2008: 8-17)

Particularly relevant for the construction industry are the education of MDA staff on the PPA and the monitoring of its application and compliance (under Goal 2); the introduction of Council Integrity Committees on a Local Governance level, and capacity-building of Council Tender Boards (under Goal 3); and the identification of potential business and corporate association, consult with and build their capacity for anticorruption initiatives, as well as create public-private partnerships including central government and LGAs (under Goal 4).

The implementation of NACSAP II is envisaged along two main mechanisms. Firstly, on the level of Ministries, Departments and Agencies (MDA) it details that all anti-corruption efforts need to be an integral part of the relevant strategic plans and the expenditure frameworks for a more coherent and budgeted implementation. Secondly, the establishment of national and sectoral consultation mechanisms is planned, involving, on various levels, representatives from the Government, civil society, the private sector as well as development partners. Perhaps most emphasised throughout the document is the need for coalition-building, dialogue and consultation processes, with the establishment of a National Anticorruption Forum as its pinnacle.

\subsection{Prevention of Corruption and Combating of Corruption Act (PCCA)}

In 2007, the Prevention and Combating of Corruption Act (No. 11) (PCCA) was enacted. The new act incorporates relevant provisions of the United Nations Convention against Corruption and the African Union 
Convention Against Corruption. As a major improvement, the range of corruption offences has been broadened significantly, and under section 5 of the PCCA gives the PCCB (see below) a broader mandate and greater operational independence. In addition, the coordination between anticorruption agencies has been strengthened.

\subsection{Prevention and Combating of Corruption Bureau (PCCB)}

In 2007, in the wake of the revision of the legislative framework, the Prevention of Corruption Bureau (PCB) was renamed Prevention and Combating of Corruption Bureau (PCCB), established as an independent public body and endowed with a broader mandate. Based on the amendment of the PCA, the PCCB's scope of operation now includes more than twenty offences, and the officers of the PCCB have been given special powers, including certain powers of investigation (but not prosecutorial powers, which is under the mandate of the DPP). ${ }^{16}$ According to their website, ${ }^{17}$ the high level goals derived from their mandate are the following:

- Enlisting and fostering public support in fighting corruption.

- Examining systems and procedures of government and public bodies to identify corrupt practices or potential.

- Providing impartial and independent advice to organisations and individuals (public and private) on preventing corruption, or reducing its likelihood.

- Advising on implementation of revised systems and procedures in government and public bodies where corruption or its potential, has been identified.

- Investigating individual, organisation (public or private) or companies suspected of being involved in corruption.

- Prosecuting where appropriate, individual organisations or companies for offences under the prevention of corruption act and others.

- Creating an enabling environment I which objectives are achieved [sic]

The PCCB is organised in four departments covering prevention, public awareness, investigation and prosecution of offenders. At the time of writing, the PCCB is established in 21 regional offices, covering all of mainland Tanzania (interestingly, Zanzibar is exempt from its mandate). It has also

16 For an overview over the history, mandate and strategic priorities of the PCCB see PCCB (2007).

17 http://www.pccb.go.tz/index.php?option=com_content\&view=article\&id=19\&Itemid $=22$ (last accessed 22 February 2010). 
established a hotline, available under the telephone number 113, where offenses relating to corruption can be reported.

\subsection{Public Ethics Secretariat}

In 2005, the list of public leaders required to declare their assets was expanded. Also, the legal framework and organisational capacities of the Ethics Secretariat has been strengthened and expanded.

\subsection{Good Governance Coordination Unit (GCCU)}

Recognising the weaknesses of the GGCU, the government decided to increase the capacity of the GGCU in order to improve the coordination of NACSAP II. The so-called Integrity Committees, established in all MDA's as focal points of anti-corruption efforts, will prepare the quarterly reports that are submitted to the GGCU as a key component of monitoring the implementation of NACSAP II.

\section{Governance Reforms in the Construction Industry}

\subsection{Public Procurement Act (PPA)}

The enactment of the Public Procurement Act No. 3 in 2001 was repealed and replaced by the Public Procurement Act No. 21 of 2004, addressing many of the flaws of its predecessor. Key reforms include the application of the Act by local government bodies; the devolution of tendering responsibility to Ministries, Departments and Agencies; and the creation of two new agencies, the Public Procurement Regulatory Authority and the Public Procurement Appeals Authority (see below). Section 72 contains an anti-bribery clause which defines a corrupt practice as "offering, giving, receiving, or soliciting of anything of value to influence the action of a public official in the procurement practice or contract execution" (PPA 2004, Section 72).

\subsection{Public Procurement Regulatory Authority (PPRA)}

Established in 2004 under the revised Public Procurement Act, the mandate of the PPRA is to support a transparent, accountable and value-formoney culture of public procurement. It replaces the regulatory function of the former Central Tender Board. Contractors must register to be eligible for participation in public procurement, and a list of registered 
contractors is distributed to all Tender Boards. They also act as an information gateway, with tender notices and procurement legislation and policies found on their website. The PPRA in endowed with provisions to blacklist companies.

Underlying their priority of supporting a transparent and due procurement process, across the top of the PPRA's home page runs a banner saying: "Our motto is promoting value for money procurement to the public. Corrupt free procurement [sic] delivers value for money procurement to the public. Let's join hands to build a corrupt free public procurement regime. Together it can be done."18

The emphasis on increasing sound public management of public procurement through an improvement of accountability and transparency is being prioritised by the PPRA. For this purpose, it has identified all relevant stakeholders and their role in the public procurement process, in which professional associations feature quite prominently (see Appendix 5 'PPRA Stakeholder Mapping', below). In 2009, an Anti-Corruption Strategy in Public Procurement (ACSPP) was developed as a contribution to NACSAP II, specifying challenges and interventions at the levels of a) prevention, b) detection, c) investigation, and d), enforcement. As part of this strategy, the PPRA developed a 'red flag checklist' covering all phases of the procurement process, which it intends to apply to all financial audits as from F/Y 2009/10. Here, the PPRA is intensifying its collaboration with the PCCB in detecting and investigating corruption in public procurement. ${ }^{19}$ In the interviews, the integrity and competence of the director of the PPRA was emphasised. However, as the following sections will show, the PPRA does not seem to be accorded much weight in terms of institutionalising rule-based practices.

18 See www.ppra.go.tz (accessed on 22 September 2009). See also the supplement of the Tanzania Procurement Journal whose editorial is dedicated to the topic of ethics and fair dealing in public procurement. The editorial column emphasises the importance for and indeed legal obligation of public officials as well as business people to adhere to highest ethical standards, but states: "Unfortunately, in this country certain practices exist and have been taken as a norm in public procurement." The column concludes with the plea: "Let us not view it [i.e. public procurement] as something which can enrich us quickly but as something which is necessary to bring development to the people through the provision of quality goods and services, in a timely manner and at prices which offer value for money to the Public" (Tanzania Procurement Journal (Vol. II, No. 12, Supplement No. 2, 14 July 2009; delivered free weekly with the Daily News; p. 1).

19 See the October-December 2009 edition of the Tanzania Procurement Journal, edited by the PPRA, dedicated to anti-corruption strategy in public procurement. 


\subsection{Public Procurement Appeals Authority (PPAA)}

The Public Procurement Appeals Authority was also established under the revised PPA in $2004^{20}$ with the aim of providing an independent mechanism through which bidders can submit complaints arising from the Public Procurement process out of court. On their website, they justify their establishment prominently with the prevention of wasted and misappropriated public funds - on their website "About Public Procurement Appeals Authority", the first of only three paragraphs is the following:

More than $70 \%$ of the Government Budget is expended in Procurement related activities every year. The Controller and Auditor General's Report that $30 \%$ of the losses report each year in the Government are losses identified with Public Procurement $[\text { sic }]^{21}$

In other words, here too anti-corruption is prioritised as a prime objective of an improved procurement system. In practice, again, it does not seem to carry much weight, according to the impression gained in the interviews.

\subsection{Implementation Action Programme for the Construction Industry Policy}

In 2006, the Ministry of Infrastructure Development launched the CIP's Implementation Action Programme (IAP). The IAP is led by a Steering Committee chaired by the Permanent Secretary of the Ministry of Infrastructure Development, with the NCC acting as Secretariat. The 14 members are ex officio representatives of, amongst others, the Prime Minister's Office (Regional Administration and Local Government), the Tanzania National Roads Authority, all registration boards of the construction industry (i.e. ERB, CRB, and AQSRB), as well as the ACET, TACECA, and AAT (MID 2006: 7$) \cdot^{22}$

The IAP identifies twelve objectives of the CIP that require additional legal backing. In fact, the IAP reads like a wish-list of professionals and experts, addressing the need for promoting technological development, or the introduction of credit bonds, training funds and further financial tools

\footnotetext{
20 See Part VII of the PPA.

21 See under http://www.ppaa.go.tz/index.php?option=com_content\&task=view\&id=17 \&Itemid=29 (last accessed 22 October 2009).

22 See MID 2006.
} 
to strengthen and protect the domestic construction industry. Relevant provisions for preventing corruption and strengthening professional standards are incorporated throughout the Action Programme. One explicit objective is 'Promoting the Prevention of Corruption in the Industry'. ${ }^{23}$ For instance, the IAP underscores the seemingly obvious enforcement of the amended Public Procurement Act to "[e]nsure transparency and accountability in procurement, design and contract administration" (MID 2006: 18, repeated on MID 2006: 22). Another example concerns the registration boards as well as professional associations, who are tasked to "[e]stablish and enforce ethical codes of conduct for the registered professionals" (MID 2006: 35). In addition, very much in the spirit of the professional associations, the CIP foresees a "[r]eview [of] enabling Acts for Regulatory Bodies to delegate some of regulatory functions to the Associations" (MID 2006: 42), with the policy objective to "[e]volve self-regulatory mechanism [sic] for their members as a way of ensuring delivery of quality service, competitive performance and prevention of corruption" (MID 2006: 42). In other words, the official discourse on the implementation of the construction industry sees a defined role for professional associations in a wide range of areas, from ethics, training and capacity-building to awareness-raising.

However, according to all interviewees with professional associations as well as authorities, the CIP has not even begun to be implemented. It is the epitome of a paper tiger. The main problem diagnosed was a lack of anyone in the driver seat; some interviewees emphasised the absence of political will-in the emphatic words of a representative of a contractor's association, "what we are missing here is a dedicated spirit of the government" ${ }^{24}$ Others pointed out the organisational reforms in the MOW absorbing all space for strategic thinking, and others again to the relative weakness of the NCC, who has a real sense of ownership with regard to the CIP, but "has not got enough muscle" in relation to other government authorities, such as the regulatory bodies. In other words, in spite of providing a serious process and detailed operational framework allocating clear responsibilities to all major stakeholders, including professional

23 See MID 2006: 56, No. 8.2.8. in the Annex of the IAP.

24 If not referenced, all the direct quotes in this chapter stem from interviews conducted in January 2010 with representatives of the construction sector in Dar es Salaam, Tanzania. 
associations, the CIP never took off_-and will, certainly in this version, never take off.

\subsection{Extent of Corruption in 2010}

Across the board, and without an exception, all the interviewees, whether from the public or private sector, confirmed that the level and exigencies of corruption in the construction sector had not abated. On the contrary, people were under the impression that it had increased. ${ }^{25}$ All the interviewees asked about the level of corruption in comparison to 2003 responded without hesitation that it was more pervasive and involved higher amounts of money. ${ }^{26}$ Mainly this seems to be due to the influx of more and bigger finances. As a well-established consulting engineer remarked: "Corruption is not going down, it is rising. I mean, in 2003 a project of USD 20 million was an exception, now it's absolutely normal". Surprising, still, given the far more advanced regulatory and legislative framework, i.e. the greater independence and stronger mandate of the PCCB, the reforms of the PPA, the greater degree of institutionalisation of the regulation boards, and the establishment and operationalisation of the PPRA and the PPAA. In fact, when asked outright about the governance reforms in the construction industry, no interviewee said that the situation had improved since 2003 . At best, some observed the situation had remained the same, in spite of the 'frills' of new institutions and amended laws. Verbatim, a civil engineer observed: "Corruption is not going down. These guys are not presenting

25 This perception of an increase of corruption in the construction sector contradicts the score of for instance the CPI that identifies a slight decrease of (albeit: overall) corruption in Tanzania in the same period (see Chapter 5 , above). This perception is confirmed by the findings of the PPRA's survey of Tanzania's procurement system, which is based on survey methodology developed by the OECD, and which compares specific dimensions the procurement system with OECD baselines from earlier surveys (PPRA 2007: 75-80).

26 The interviewees were referring to corrupt practices framing the project cycle of ordinary tenders issued by the public sector. However, two interviewees also pointed out that 2010 is an election year, and hence the tussle about and the 'politicisation' of tenders and their allocation as part of political campaigns was already palpable, with the concomitant increase in corruption. One well-connected engineer made an interesting point about the struggles within the system: "Many people do not know this, but there is corruption within the political system. Ministers are lobbying MPs to rubberstamp their projects. Parliamentary committees have become very powerful for this reason". Tying this observation into the analysis on politics and political order in Africa discussed in Chapter 1, above, this kind of corruption is neither neo-patrimonial nor 'disorderly', but very much like the political corruption found in American or European politics (for examples and analyses see, for instance, Transparency International 2004). 
the right ways to fight corruption. The tools are there. If government is serious, then things should happen".

There was a definite sense of powerlessness pervading the comments on the extent of corruption. In distinction to 2003, where articulations of corruption were shaped by outrage and at the same time a sense of agency and promise, the interviewees now shrugged their shoulders - not without indignation, but coupled with resignation: "Corruption is a problem, but what can you do about it?" asked a consulting engineer, nota bene of an association which had been at the forefront of defining best business practices in 2003. This is a sentiment echoed by many others in a state of more or less agitation. After describing the infinite and often highly perfidious ways that tenders were manipulated by public officials, a successful and engaged quantity surveyor summed up the situation in the following way: “The enemy is very smart, I don't know whether it is possible to do anything". As a result his strategy was to try and stay clear from public tenders, and stick to projects in the private sector. "I would prefer to have a handful of small or middle-sized private projects than one or two big public projects. They are a waste of time and money". This strategy was enthused by most other interviewees, who confirmed that corruption in the private sector was minimal, and, another distinction to public sector projects, the efficiency of the project management itself was far greater: "They want value for money". Only: not many professionals are in a position to make acquisitions and secure projects in the private sector, either for lack of capacity and experience, and/or because major investment projects are only available in Dar es Salaam and one or two other cities. In the regions and rural areas, public investments still constitute the overwhelming majority of projects, from roads, waterworks, irrigations schemes, infrastructure, power supply, etc. In other words, this strategy of 'exiting' the public sector, a real alternative in comparison to 2003, when there were hardly any private projects available to local companies, is limited to the select few. And for the public sector there still seems to be one truth: "Everyone is corrupt, even every service in rural areas", according to a contractor.

So, just comparing corruption in the construction industry between 2003 and 2010, the one major space easing the pressure to (be) corrupt noted by the majority of respondents is not the firmer normative framework, the greater legal coherence, the institutional filling of regulatory voids, or even the professionalization of the industry-no, it is the increase of private investment in construction. A conclusion reflecting rather poorly on the implementation and internalisation of governance reforms. 
I shall discuss how this situation frames the room to manoeuvre of professional associations.

\section{Professional Associations and Corruption in the Construction Industry}

In spite of the openness of the findings of the case-study of 2003, I had formed at the back of my head the hypothesis that given the structural reforms, the improved legal framework of public procurement and more coherent regulation of professionals, professional associations would become more asserted, stronger and more assured in their professional standing within the construction industry and policy making processes. In other words, in an admittedly highly optimistic Weberian reading, I assumed that articulations of corruption referring to particular normative frameworks, professional ethics as well as professional industrial policies would, firstly, lead to a profiling and 'hardening' of their professional identity, and secondly, to an at least partial hegemonisation of governance discourses by the associations, manifested in more resources and a stronger voice. This, in my opinion rather neat hypothesis begun to crumble with the very first interviews - and, a bit like all the kings men and all the kings horses attempting to put Humpty Dumpty together again, I have not been able to reassemble it since. Yes, the discursive terrain that presented itself in 2003 was, in 2010, transformed through the remarkably extensive regulatory reforms described above. Yet it seems that this formally restructured construction industry (one could also say: the dislocations in the discursive landscape) has not expanded the hegemonic power of professional associations, although their representations of corruption were, as the case-study of 2003 indicated, doubtlessly formative to the ways these reforms were articulated and formalised. However, instead of this process leading to an increase in the democratic space of professional associations, quite the contrary seems to have happened. Firstly, corruption seems to have all but disappeared as an empty signifier - not, as was indicated above and will be shown through the eyes of professionals, because of a lack of nodal points that 'corruption' could connect to, but because the hegemonic representations of official regulatory institutions (especially the regulation boards) has proved to be more dominant, 'smothering' and appropriating the emancipatory corruption discourse of professional associations. This holds not only true for the corruption discourse; it seems that in general the articulatory and practical spaces of professional associations has been filled with official articulations, thus 
closing down on differential, democratic spaces. This argument will be substantiated below in the sections talking through the different dimensions affecting the identity, resources and boundaries of the professional associations.

Professional Associations: In 2009, three professional associations had disappeared from the NCC's list of professional members, ${ }^{27}$ and two more had been added, including CATA. ${ }^{28}$ Given the small number of professional associations and the size of the private sector in construction, this is quite a remarkable fluctuation. Interestingly, in 2009 the contractors working in the informal sector formed a professional association (Tanzanian Association of Informal Constructors (TAICO)), with the support of the National Construction Council and the UNDP. ${ }^{29}$ According to two interviewees, in 2008 the establishment of an apex organisation for all professional associations was induced. However, its establishment has not progressed since.

Membership: All the associations are still struggling with a lack of interest and lack of members. This has two main repercussions: the first is a financial problem, as the associations are largely membership-financed. The second, linked to the first, is the problem of lack of membership. The associations all struggle with relatively weak membership numbers and the concomitant lack of representativeness - an issue unchanged since 2003. "You need a strong voice, the voice comes from the members. You cannot speak with a strong voice if you have less than $50 \%$ of professionals as members", said the executive secretary of a formerly influential engineers' association. As an example, according to the executive secretary, ACET had an estimated average of less than four new members in the

27 These were the Tanzanian Association of Contractors (TACA) (which according to informants was never operational), the Association of Electrical Contractors Tanzania (AECT), and the Association of Valuers and Estate Agents (TIVEA), none of which were included in the study of 2003 .

28 The other association is the Tanzanian Institution of Arbitrators (TIArb), which was also not included in the case-study of 2003.

29 The informal sector was not included in this case-study, and this point shall not be elaborated any further. However, from the interview with the responsible desk officer and from the documentation provided by her, there are some interesting observations that can be made. The prime objective of TAICO is to improve the exploitative work-conditions and wages of the informal workers. This incongruous hybrid type of association between the formal and informal seems to be an indication of a) the increasing importance of formal recognition to have access to more and better paid jobs, b) the increasing importance of speaking with a collective voice to influence the sectoral framework, and c) the increasing confidence about and engagement to demand basic rights. Tellingly, TAICO's constitution does not include any provisions on professional codes of conduct (see TAICO 2009). 
past years, and in 2008 no new member at all. In 2009, however, according to the executive secretary the 'value added' provided by the directory they had recently published (see under 'activities' below) attracted seven firms and 12 individual members, which constitutes a remarkable success. Still, the issue is both a problem of numbers and of weight. On the one hand, the associations are struggling with attracting sufficient members in absolute terms; but equally weakening is the fact that the associations are not necessarily attracting the important players, i.e. the bigger firms or the experienced and established professionals. The latter seems a particular problem for 'established' professions, i.e. the engineers and the architects.

All the associations included in this study had a membership of under $50 \%$, although exact numbers were hard to get, also because the distinction was made between 'active' members-i.e. members who paid their membership fees-and other members. Examples are ACET, which has about 90 members out of an estimated 200 registered consulting engineers; TACECA, which has an estimated membership of approx. 300 out of a total of more than 1000 registered civil contractors; CATA with an estimated membership of approx. 500 (of which about $35^{\circ}$ 'active' members) out of a total of about 4000 contractors; the AAT has approx. 80 members (out of approx. 250 registered architects). The TIQS seems to have the best ratio, namely 80 individual members out of a small community of about 150 registered quantity surveyors. However, of the 80 members only about 40 are actually registered quantity surveyors, the other members are only graduate members. The problem of lack of members as well as lack of commitment by the members in paying their fees was emphasised throughout the interviews, particularly in the small associations.

The reasons for this scant interest given were mainly lack of a sense of community within the professions themselves, even within the more established professions. "They do not see the need for us", was diagnosed self-critically, or, with a more cutting assessment of the absence of cohesiveness of the professional community: "They are not interested in the future of the profession"-be it because many professionals are content with the existing situation and opportunities, be it because they are not sufficiently aware of the work of the associations, or be it because they quite literally do not subscribe to the objectives of the association. Many are members (in fact, the ERB stipulates membership in a professional association as a condition for registration, be that a national, regional or international association), but do not pay membership fees or take part in the annual meetings or other events. Other reasons given were not just 
lack of interest, but also lack of time: "people are willing, but they are too tied up with their own business", was observed by interviewees of several professions, i.e. everyone is so busy that they cannot or do not want to make time for additional (especially voluntary) engagements.

An additional point not raised in the interviews of 2003 was now addressed quite emphatically. The registration boards are mainly financed by the professionals themselves, their fees being statutory for registration. The sentiments within the professional community with regard to the associations seems to be that "they pay fees to CRB, why should they pay us too?". This is especially pertinent as the registration boards have taken on many functions that the professional associations formerly filled, most notably professional standard setting. There was a distinct sense conveyed by most of the associations themselves that, indeed, they were not offering any 'value added' to the community, because they are too small, too poor, and too weak to influence official policies. But in particular, it was emphasised that they were weak in terms of status as well as resources vis-à-vis the ever stronger registration boards.

Staffing: The associations vary in terms of staff available to them. In comparison to 2003 , there is a small professionalization to be witnessed, with more associations endowed with permanent staff. However, the staff numbers are still very small; for instance, ACET has a staff of four (with a paid executive secretary only since 2005); IET has a similar set-up. TACECA's staff is down from four full-time positions in 2009 (including an advocacy position) to two in 2010 (the Executive Secretary and the Office Manager), although they have been successful in attracting funding. But most of the associations were completely reliant on voluntary work, which constitutes a major problem. Human resources to convene and inform members, plan and execute the variety of activities is a very scarce resource. The question: "When to find time?" was raised several times in the course of the interviews, not to mention the question how to find money. The impression was that the smaller associations, such as the TIQS or AAT, are completely reliant on less than a handful of persons (in both cases without any permanent staff), and the others are all also struggling with constraints.

Activities: Most of the associations were involved not so much in outright advocacy, but were concentrating mainly on technical activities, such as improving specific provisions of contracts, procurement stipulations or training. To secure their purpose and status, most the associations were in one way or the other cooperating with the relevant regulatory boards on training. Health (such as HIV/AIDS, or health and safety on construction 
sites) seems to be one area of advocacy and engagement, which is also supported by donor agencies and international organisations. ${ }^{30}$ Two of the associations were primarily concerned with compiling and publishing a directory of all professionals in the community. ${ }^{31}$ As such a directory had not previously existed, or urgently required an update, these activities were seen to be of immediate use to the members and beyond. All associations were involved in activities to protect their profession and specific quality standards, for instance through specific contractual stipulations or financial arrangements. Also, new ways of cooperating with the authorities were being sought, for instance, through MoUs on areas of activities and responsibilities.

Where possible, the associations were seeking to participate in intergovernmental fora that in most cases go beyond the construction industry. One important vessel is the Tanzanian National Business Council, where "our voice is heard in the highest level", as representatives of two of the associations underlined. General opinion was that influence had to be sought as close to the 'realms of power' as possible, going beyond the immediate regulatory and institutional framework by connecting to 'higher' discourses on public-private cooperation and dialogue.

Notable was that 'corruption' had all but disappeared from the agenda of the associations. Whereas in 2003 nearly all associations had some project, activity or forum articulated around corruption in a wide sense (i.e. professional ethics, improvement of legal framework, more effective and transparent implementation etc.), in 2010 no discourse on corruption connecting up to other discourses (in this sense: public discourse) could be discerned. Of all associations, TACECA was the only association that has a project in the pipeline, but a project that has been lying dormant for the past few years due to lack of funding. ${ }^{32}$ According to the leading represen-

30 See the activities by TACECA, who are engaged in the prevention of HIV/Aids in road projects, or the IET, who in collaboration with the ERB and OSHA are aiming to include health and safety in the criteria's of the tender boards.

31 The two associations are TACO and ACET, so this seems to be a particular concern of the consulting industry, to enhance visibility and access to information on companies.

32 One proposal on 'TACECA programme monitoring Anti-corruption initiatives in the construction sector' had been prepared by the ITT (UK) for TACECA in November 2007, but found no further funding (unfortunately no copy of this proposal could be obtained). Before that, in 2006, TACECA outlined another governance project on 'Design of a System for Monitoring the Implementation of Policies and Legislation Focusing on Local Civil Engineering Contracting Subsector' (see picture), which, amongst other objectives, includes the identification of mechanisms to "assess issues hindering the growth and improvement of local civil engineering contracting sub-sector" (TACECA 2006: 6) which, the draft report 
tatives of TACECA, the reason given by the funding organisation was that corruption was now an issue taken up by other, specialised civil society organisations, and hence there was no need for a professional association to address the topic.

The general impression gained from the interviews was that discursive articulations of corruption have significantly decreased both in general representations within the public media as well as in the more circumspect field of construction industry policies. In spite of the problems that still pervade the construction industry, the constraints on (legally) profitable, quality work and on the professional integrity of professionals in the construction industry, the professional associations are not addressing the issue in a programmatic fashion. TACECA is the only association that has attempted to kick-start it in a more systematic manner, but has failed due to lack of funding. This does not mean, however, that the topic has lost its salience for the associations, or that it is not addressed in more informal ways. A leading member of the TIQS exclaimed "in all these forums and meetings [with government], corruption is always a topic, but the Minister or the Deputy Minister does not listen". This sentiment was echoed nearly verbatim by other interviewees from professional associations, embittered that "we shout, but they do not want to hear us". There seems to be a particular 'deafness' of the public sector to the voices of the professional associations, in general, as will be commented further down, but in particular with regard to issues of corruption. This lack of impact may be compounded by the problem of social compacts that was already diagnosed in the case-study of 2003; as a civil contractor pointed out, describing encounters with the government: "You talk, you agree, but then nothing is implemented the way that you think it should be"-the associations' voice "goes in one ear, out the other", as his colleagues put it in a different interview.

concludes, "include poor technical and management skills, lack of investment capital and finance, poor management organization, lack of access to work opportunities, globalization, marginalization and corruption" (TACECA 2006: 53). The Terms of Reference were laid out by the funding organisation, Business Environment Strengthening for Tanzania (BEST), supported by the World Bank, the government of Denmark through DANIDA, of Sweden through SIDA, of the United Kingdom through DFID, and the Embassy of the Kingdom of the Netherlands. 


\section{6. 'Our voice is not heard': Perspectives on Public Officials}

The discourse on the public sector as articulated by professionals in the private sector has mutated slightly. The problem of wage asymmetry is not accorded the same weight as it did in 2003, although there is still a discrepancy of about 1:3, ${ }^{33}$ according to an eminent board member of the ERB. As he accorded, this discrepancy still has a potentially corrupting effect, but it was not a feature problematised further in other interviews. What was striking in comparison to 2003 is that the public sector was characterised in similar terms by the professionals, and yet with some very significant differences. The distinction between 'us' and 'them' was still being drawn in terms of both attitude and greed: "Government officials are not professionals, they cannot see. It is a problem of mind-set, not that they are benefiting a lot. If they were pushed out of the public sector into the private sector they would realize", as a civil contractor observed, emphasising on the lack of exposure and professional experience of senior officials. This assessment of obstructive senior officials was resonated by a consulting engineer: "The wages are not a problem, just greed. It's not the ordinary person in the office, but the senior persons, those persons with the power to blacklist a contractor, to blacklist a consultant, those with a good salary, with extras perks. They want to buy a new car, they want to build a new house in one year. So they resort to malpractices". As an established and recognised contractor lamented, echoing others: "Why should they not work for money?", referring both to the greed and discretion encountered in public officials, as well as to the difficult economic situation of contractors, whose profit margins are still and perhaps increasingly squeezed by competition and corruption. The comments also, of course, point to a particular entrepreneurial ethics, a pride in earning one's own money through productive and professional work (as opposed to the 'unproductive' bureaucrat).

The great difference between 2003 and 2010 is not, then, a change in mind-set and official ethics, or more effective normative sanctions, as might have been expected from transformed regulatory landscape. No: the difference lies in the articulations around the space that regulatory institutions are taking up. Not in the sense of creating and protecting spaces

33 The example given was for a young graduate engineer, who would earn approx. USD 400 a month in the public sector, compared to approx. USD $1200-1500$ in the private sector. 
for professional practices, but in the sense of encroaching on the spaces of professional associations in terms of standard setting, outreach, training and definition of best practices. All associations of the construction interviewed were agitated about the fact that especially the registration boards were taking on more and more functions that hitherto had been exercised by the professional associations - and which, as was strongly felt, the associations were far better placed to exercise. Since they have been established, the registration boards "are slowly showing their muscle", as was stated with regard to their expansion of activities. Indeed, both the ERB as well as the CRB's mandate has widened, and they are increasingly active in accreditation, training as well as outreach, for instance, through their AGMs or through local consultative meetings. The need for the registration boards was not disputed, on the contrary, but the need for complementary spheres of activity was underlined. Statements such as the following were regular features of the interviews: "The CRB should not act as police, they should support us". "Why are they conducting training? These are things that we are far better placed to do." "We are striving for CRB [sic] not to jeopardize the work that should be done by the associations". The legitimisation of their 'better placement' was drawn from three reasons: firstly, through the associations autonomy and independence (a distinction made by statements such as: "the ERB cannot do anything against the government's will"); secondly, responsiveness to the needs of the profession (examples abound, from health and safety requirements to specialised contractual arrangements); and thirdly, through their more relevant degree of expertise, not least through continual interaction with regional and international apex organisations, with which all associations were involved in.

Problematic remains the scant recognition that is accorded to the associations, in spite of their formalised interaction and consultation process with regard to various institutional and legal reforms (which begun with the establishment of the registration boards and has continued over the PPA and its amendments, the CIP and its IAP, as well as to various specialised technical specifications), as well as the frequent physical proximity and interpersonal exchanges. ${ }^{34}$ The complaint and agitation with

34 The interpersonal exchanges are quasi-guaranteed because of the small size of the expert community in the construction sector. The representation on the boards as well as other official meetings and committees are routine meeting-places for public and private representatives. In addition, some associations are actually located or have an office space in the same building as the registration boards, such as, for instance, the IET. 
regard to the 'deafness' of public officials and institutions when it comes to addressing corruption is resonated on a larger scale: professional associations, to a greater or lesser extent, are not mute, but their voices are muted. Their efforts at hegemonising representations, be it on corruption or others, are characterised by palpable power asymmetries, by highly uneven endowments with symbolic and material resources.

A case in point is the official, statutory guaranteed representation of the professional associations on the registration boards. Most interviewees from the associations acknowledged that communication had become easier as a result of the official representation and the formalised encounters and spaces of communication. The interpretation on the effects of these formalised encounters, however, differed from association to association, depending on their relationship with the registration board in question. One problem that loomed large was that, whilst the associations have the statutory right to nominate candidates for the boards, it is at the discretion of the Ministry to appoint the final members. Evidently, the associations strongly resented the fact that they were disenfranchised in terms of 'real' representation.

At the same time the cooperation between the registration boards and the associations seems to have drawn closer and become more formalised. In their quest to secure own spaces and counteract the traction of marginalisation, the associations seek to formalise their cooperation with the registration boards. As mentioned above, the IET is in the process of drawing up a Memorandum of Understanding between themselves, the ERB and the Occupational Health and Safety Authority (OSHA). One objective of the IET is the official recognition of health and safety standards by the PPRA as a criterion for awarding tenders. ${ }^{35}$

The division of labour between the associations and the registration is irksome to all associations. On the one hand the associations feel marginalised and expropriated by the expansion of regulatory activities. On the other hand, there is a sense of abuse of their expertise and voice, which is called upon only when it suits the registration boards. This, interestingly, also holds true in one case where the registration board evidently calls on the association to criticise certain government policies, which the registration board, as a government agency, could not do itself. "But these are not necessarily our opinions or our stakes”, was complained. This is a particularly interesting case of inverted hegemonisation, showing again

35 Unfortunately no copy of the MoU could be obtained. 
the shifting boundaries between and within both government as well as associational discourses.

What was remarked in 2003 still holds true in 2010, namely the importance of individuals. The professional community engaged in policy work is still very small, and personal relations are important. In many cases the integrity or capability of a particular executive of a public agency was acknowledged, also underlining the fact that this rendered communication and professional recognition much easier. An influential factor seems to be the professional qualification of the public official in question, i.e. whether he (mostly he, not she) is from the same professional community or not. This is especially felt within the non-engineering community, due to the dominance and establishment of the engineering profession in the Tanzanian construction industry and policy framework. Remarkable is that at least two important institutions of the construction industry, the NCC and the PPRA, are directed by persons who are generally acknowledged to be competent and genuinely engaged in promoting professionalism. However, without contesting the integrity or the skills of these individuals, the institutions themselves were not seen to be very effective, placed as they are within a disabling environment.

As indicated above, however, the discursive landscape has changed. Those associations with sufficient human resources are increasingly articulate in fora that go beyond the construction industry, in committees or high-level meetings that create overarching formalised nodal points between the public and the private sector. Interestingly, better inter-sectoral communication is also one of the prime priorities of the NACSAP II, which seeks to create a variety of local to national stakeholder platforms. In the construction industry, it is perceived that, as was outlined in the previous sections, the Cabinet and in particular the relevant Ministries (MID and MOW) are not very strategic or proactive in designing, structuring and implementing industry policies. Hence, the need to be 'heard' in other spheres seems to lend itself to discourses of professional interests. One of the most important cross-sectoral vehicles seems to be the National Business Council (NBC), which is chaired by the President, and has twenty members of the public sector (government and senior public officials) and twenty members from business. The latter include representatives of the professional associations, such as TACO or TACECA. As a civil contractor remarked, "there, our voice is heard in the highest place".

To conclude, two features are notable. The first is that professional associations are at pains to take their representations out of the construction industry, and be heard in the wider and weightier forum of selected 
business interests. The second is the emphasis on non-adversarial politics. As the same civil contractor, who represents an association in the NBC, emphasised: "When talking to government we say we are not hostile, we are trying to build a friendly environment." Professional associations are endeavouring to engage in dialogue, not confrontation, with the stateand this increasingly beyond the narrow confines of the construction industry, in which, in addition, due to its still relatively small size persons and personalities know each other only too well.

\section{Hegemonies and Fixations of Corruption: Conclusions in Space and Time}

Looking back, at the end of the case-study in 2003 there was no clearcut conclusion on the stability and closure of professional identities. The articulations of professional identities and purposive representations of collective interests coupled with political claims were, at that time, still relatively fresh. Very clearly, at the time they were restructuring and being restructured by the evolving regulatory framework and the emergence of new official actors. This restructuring process was inscribed deeply by the donor discourse on governance and corruption, which provided the material and epistemic frame of reference for relevant governmental policies in the construction industry and, more generally, with regard to specific anti-corruption measures. The conclusions were very much in terms of a snapshot: on the one hand, professional identities were becoming firmer and more universalised through processes of articulation that employed corruption as an empty signifier. Corruption, in this understanding, served to unify differential demands, i.e. the distinct demands of the different professional associations themselves (distinctions that are sharply drawn), as well as differential demands inscribed across the public-private divide. Thus the meaning of corruption is emptied out and refilled with particular meanings that all refer to a common universality, enabling and creating a set of relational differences: a chain of equivalences that allows these distinct and different identities to relate to each other. ${ }^{36}$ Corruption as an empty signifier renders demands of the Anti-Corruption Machine (as embodied in relevant donor discourses), demands articulated in national development policies, demands emanating from public institutions as

36 For elaborations see Laclau (2000, 2004), Gasché (2004), or Norval (2004). 
well as the demands from the professional associations mutually legible. In the process, the different hegemonic representations undergo modifications, constructing and experiencing new differences (e.g. between different professional associations, or between professional associations and regulatory bodies) as well as new equivalences (between particular professional associations and regulatory bodies, or between professional associations and national business interests).

In 2003 , the jury was out with regard to fixations of the hegemonic representations and delineation of identities of professional associations in the construction industry. Both a successful hegemonisation process was thinkable, with the hegemonic representations of professional associations forging chains of equivalence with the social imaginary emerging in the process of democratisation, pluralisation and liberalisation. 'Successful', here, would mean that the particular meaning of corruption as articulated by the professional associations, demanding political and economic spaces that create professional recognition, professional integrity and rule-based, legal profit-making opportunities, would acquire a universalising effect. This did not seem unlikely, especially as the governmental discourse on development, the donor discourse on governance and anticorruption, as well as more concretely the legal and institutional framework were all operating with similar statements. At the time, the elements of articulating corruption in this emancipatory sense were readily available (a contingent process which is by no means predetermined), and lent themselves to being filled with distinct and different representations.

At the same time, the dominant practices of corruption were framed by a different set of logics-profit-seeking and profit-making 'no matter what', largely unconstrained by legal sanctions or ethical norms. This counter-discourse squeezed the spaces of professional associations considerably. On the one hand, it made their demands of social transformation more urgent, more pressing, as reflected both in the observed belligerence or frustration of responses, as well as in the frequency that 'corruption' was problematised and employed as pars pro toto for disinterested, self-serving public institutions and political marginalisation. On the other hand, the dominant practice of corruption characterising the construction industry-a hegemonic representation sui generis, as indicated in the conclusions to Chapter 3-deprived the professional associations of the material and, to an extent, the symbolic (in terms of credibility and legitimacy) resources to articulate their demands. The increasing numbers and diversity of articulations by professional organisations, the regulatory changes, and increased interactions of professional associations with 
public agencies, with 'corruption' acting as an empty signifier, could be interpreted as an emancipatory process, leading to more diverse political and economic spaces for professional associations. The demands, statements and practices of professional associations had obviously made their mark, resulting in concrete regulatory and institutional reforms-albeit not to the extent hoped or demanded. In addition, the heterogeneity and variety of linkages and coalitions between and across the public/privatedivide made a more open, more emancipatory process thinkable. But on the other hand, the dominant practice of corruption and the discursive closures witnessed at the level of national politics in terms of authoritarian trends were structuring the political spaces hierarchically, endowed with and exerting far more power than the small and weak professional associations could ever hope for.

In the years between the two case-studies, the structuring of the political spaces and the delineation of professional identities underwent dynamics that were not predicted in 2003. The first and foremost conclusion is that corruption as an empty signifier has waned. 'Corruption' is still a dominant discourse of national development and growth, but it has lost its power to forge chains of equivalence for emancipatory micro-struggles. The democratic spaces and standard setting power of professional associations has decreased significantly. Although professional associations are seeking to reach out beyond the confines of the construction industry to high-level meetings, the nodal points are not forged by the signifier corruption. Corruption is still being articulated by professional associations, but not in a programmatic form - partly, of course, due to lack of donor support, who have 'externalised' the topic of corruption to specialised civil society organisations; partly due to governmental practices that foster impunity. In 2010, corruption is articulated in far more informal, more indirect ways by professional associations, thus losing much of its hegemonic power. This loss of power and resonance is reflected in the relative loss of recognition and visibility of professional associations in this period. Evidently, I do not mean to say with this that 'corruption' is the only empty signifier that is capable of articulating the professional demands and interests for a rule-based, democratic social order, or constructing the nodal points strong enough to inscribe their discourse in the discourses of other (in particular: public agents) social agents. But in 2003 'corruption' seemed to be endowed with the right ingredients against the right horizon to do so. But the empty signifier 'corruption' has shrunk and become dissipated, not evocative enough to synthesise collective action or social imaginaries anymore. 
Interestingly, the actor articulating corruption most forcefully and coherently is a regulatory authority, namely the PPRA. The PPRA is clearly seeking to construct corruption as an empty signifier, seeking to represent the 'unity' of regulatory institutions and professionals within the construction sector as well as that of sectoral and national reforms as unified in the fight against corruption and for more efficiency and professionalism. The discourse of corruption is employed to delineate the regulatory body's identity, seeking to bolster its own visibility and authority. However, as far as could be ascertained, professional associations have not sought to link up to these articulations (as indeed the PPRA has not reached out to them), nor do these articulations show much traction with other governmental agencies. The lack of hegemonic radiation has to do with the social actor seeking to fill it with one particular meaning; in this case, the PPRA who, in spite of the importance of its mandate, itself does not occupy a very powerful position within the governmental administration as well as within the construction industry.

But this lack of hegemonic radiation also demonstrates that corruption as an empty signifier has lost its allure, its gravitational force-it is not powerful enough anymore to link up discourses, to collapse frontiers between different identities. The different social agents in the public as well as private sector are concerned with the construction of other empty signifiers. In this, certain actors are far more successful than others. Overall, it seems as if the hegemonising representation of the regulatory bodies has appropriated much of the differential identities of the professional associations. By taking over terms, values and practices such as 'professionalism', 'quality', or 'training', the regulatory bodies have also taken over the spaces formerly created and occupied by the professional associations. Instead of securing spaces, in a paradox twist the successful discourses of professional associations have served to disempower them. In effect, the process of establishing a comprehensive regulatory framework to safeguard professional quality and practice has led to a squeezing out of professional associations' spaces. The de iure functional differentiation this process is embedded in, in principle welcomed and sought, has not resulted in de facto functional differentiation, which would allow and indeed necessitate a diversity of logics. Instead it has resulted in building and reinforcing the power and the outreach of the state.

Important at this point is to note that although the state's power has definitely been extended by this regulatory process-and evidently in very real senses - this power is not as monolithic as depicted in many neo-patrimonial accounts, or as single-logic-driven as more radical 
accounts of instrumentalisation and criminalisation would have it, nor indeed as deterministic as accounts of socio-cultural frameworks outline (see Chapter 1, above). The power of the state is transformed and consolidated through idealtypical rule-based institutional change, effecting and enunciating certain democratic moments. However, the effects of this transformation are far more diffuse than anticipated. It does not fall neatly into the category 'stronger institutional framework', as evidently the institutional framework, whilst largely endowed with authority, does not enforce its rules. It does not fit neatly into the category 'increased authoritarianism', as there is a marked heterogeneity in terms of integrity and 'culture' of public agencies to be observed. And it does not fall neatly into the category 'democratisation', as the power asymmetry between the public and the private sector (at least the part of the private sector observed) is pronounced.

It is precisely this uneven spread of power within the social order (beyond the public/private divide) that needs to be understood in a more discerning fashion. Professional associations are endowed with very few resources. ${ }^{37}$ They do not have the symbolic or the material resources to 'make themselves heard', to make officials and public institutions listen and act. Corruption as an empty signifier has lost the power to capture the imagination and, not least, the funds to resonate in public. I shall return to the question of inequality in power relations and the effects on the structuring of political spaces in the concluding chapter. Suffice to say at this point that the statements made by professional associations (and indeed other actors within the construction industry) on corruption are too dispersed and too irregular to coalesce to a discursive formation, to a regular and dominant representation that radiates into practices, articulations and statements of other social actors. There is a definite sense that the window of opportunity, the historical horizon against which such emancipatory statements could be made legible and audible, has closed. Whereas in 2003 there was a distinct (if brittle) sense of professional identities and interests being profiled and represented in official discourses, these have now been hegemonised by official discourse. Instead of achieving a hegemonic representation themselves, the articulatory process (which had hegemonic moments) has lead to official discourses totalising these claims. The nodal points constructed by the professional associations have

37 Or, put in Bourdieu's terms, they occupy very weak positions in the social terrain (Bourdieu 1985). 
shrunk to highly formalised practices: to Memorandum of Understandings, to the formal division of labour between them and the registration boards-but framed by a clear and known power asymmetry.

Thus, the political spaces characterising the construction industry in Tanzania are structured by an intriguing mix of stronger democratic politics on a national level, weaker democratic identities on a sectoral level, stronger regulatory institutions and representations, and, certainly within the construction industry, a shrunk public (in the sense of shared) space in which meanings and claims can be heard. But although the case-studies have illuminated some of the processes through which democratic discourses are inscribed, articulated or, indeed, are disarticulated, they say very little about the conditions under which such democratic social change becomes possible in a non-deterministic, non-linear way. Obviously, the case-studies were only focusing on a very narrow strip of social order over time and in space. However, the question merits our attention on a more fundamental level. As Aletta Norval argues in reference to equality (as an intrinsic element of democratic politics), constitutive is

a change of perspective, of aspect, forced upon the existing social order, which institutes a new space where meanings may be shared. To repeat: there is not first a shared space in which all reasons and demands may be heard equally and into which new demands can be inscribed, but rather this shared space of reasons needs to be instituted, often through practices other than verbal argumentation. Thus the verification of the presupposition of equality always takes place through the rupturing of a given order by disagreements (mésentente) that challenge existing orders and institute new spaces of meaning, which may become sites of emancipation, or alternatively may become ossified over time (Norval 2007: 78). ${ }^{38}$

To rephrase it blandly: how are new spaces instituted-and what constitutes emancipatory sites rather than sites of ossification? I shall turn to precisely this process of changed aspects forced upon the social order, this disruptive process of challenges and disagreements, as well as the question under which conditions new spaces of democratic meaning can be instituted in the following, concluding chapter.

38 Evidently, Norval develops her argument in explicit contradistinction to deliberative, liberal as well as critical theoretical scholars. She draws heavily on Jacques Rancière, who notes that "proving one is correct has never compelled others to recognize they are wrong". As a result, the "affirmation of the right to be correct is dependent on the violence of its inscription" (Norval 2007: 77, quoting Rancière 1995: 49). The kind of 'violence' of such inscriptions generating contemporary democratic politics is, perhaps, still underexplored. 